\title{
EDITORS
}

A. F. Ga R vie, M.A., Department of Greek, The University, Glasgow G128QQ Professor H. M. Hine, M.A., D.Phil., Department of Humanity,

St. Salvator's College, St. Andrews, Fife KY16 9AL

BOARD OF MANAGEMENT

Professor E. J. Kenney, M.A., F.B.A. (Chairman)

Professor D. M. MacDowell, M.A.

Professor W. G. Arnott, M.A., Ph.D.

R. Wallace, B.A., M.A.

Representing the Council

Professor C. Collard, M.A., M.Litt. (Hon. Sec.) Association

Mr M. Winterbottom, M.A., D.Phil., F.B.A, representing the Oxford Philological Society

Mr J. Diggle, Litt.D., F.B.A. (Hon. Treas.), representing the Cambridge Philological Society

Books for review should be addressed to the Editors, c/o Journals Production, Oxford University Press, Walton Street, Oxford OX2 6DP. Authors and publishers are advised that excerpts or extracts from periodicals or other works will not be reviewed or listed among books received unless they are also published separately.

Correspondence concerning advertisements to appear in this journal should be addressed to the Journals Advertising Coordinator, Oxford University Press, Walton Street, Oxford OX2 6DP. All other communications should be sent to one of the Editors.

The annual subscription is $£ 23$ (N. Amer. US \$45, UK £19), with single issues at $£ 13$ (N. Amer. US \$27, UK £12). Prices include postage by surface mail or, for subscribers in the USA, Canada, Japan, Australia and New Zealand, by Air Speeded Post. Journals are sent to India by air-freight. Airmail rates are available on request. Back issues are sold at the current single issue rate and complete back volumes are sold at the current single issue rate multiplied by the number of issues in the volume. Issues prior to Volume 35 are available from Dawson Back Issues, Folkestone, Kent CT19 5EE.

\section{Order Information}

Payment is required with all orders and subscriptions are accepted and entered by the volume/s. Payment may be made by the following methods:

Cheque (made payable to Oxford University Press)

National Girobank (Account 500 1056)

Credit Card (Access, Visa, American Express, Diners Club)

UNESCO Coupons

Bankers: Barclays Bank Plc, PO Box 333, Oxford, UK

Code 20-65-18, Account 00715654

Please send orders and requests for sample copies to:

Journals Subscriptions Department, Oxford University Press, Walton Street, Oxford OX2 6DP. Telex 837330 OXPRESG 


\section{CAMBRIDGE}

\section{The Metamorphoses of Persephone}

Ovid and the Self-conscious Muse STEPHEN HINDS

Dr Hinds gives a close reading of the two accounts of the myth of Persephone to be found in Ovid's poetry, the one in Metamorpboses 5, the other in Fasti 4. The book is at once a literary historical enquiry into the double transformation of the rape of Persephone and a critical exploration of the self-conscious delight in language and writing manifested in and between these twin Ovidian narratives.

\section{Propertius: A Hellenistic Poet on Love and Death}

\section{THEODORE D. PAPANGHELIS}

This book examines the theme of erotic death which characterised the poetry of Propertius. The author studies the structure, imagery, word-play, ambiguity and allusive technique of the elegies, revealing a 'learned' and sensuous poet building up his poetry with material whose significance for his aesthetic has not always been fully appreciated.

\section{$248 p p . \quad 0 \quad 521323142 \$ 25.00$ net}

\section{Vox Graeca}

The Pronunciation of Classical Greek

\section{W. SIDNEY ALLEN}

This is a new and enlarged edition of Professor Allen's highly successful book on the pronunciation of Attic Greek in classical times. In this third edition, Professor Allen has in particular revised the presentation of the controversial question of stress; the chapter on quantity has been extensively recast; and an appendix has been added on the names and letters of the Greek alphabet.

$$
\begin{aligned}
& 200 \text { pp. } 0521333679 \text { Hard covers \$25.00 net } \\
& \text { o } 521335558 \text { Paperback \&8.95 net }
\end{aligned}
$$

\section{A Hellenistic Anthology NEIL HOPKINSON}

This book is an anthology of Greek poetry written during the third to first centuries BC. It is intended to make available to undergraduates a selection of texts which are for the most part not easily accessible elsewhere. An introduction sets the poetry in its cultural and historical backgrounds and a full commentary elucidates problems of language and reference in the texts.

Cambridge Greek and Latin Classics

$$
\begin{aligned}
& 304 p p . \quad 0521306965 \text { Hard covers } \$ 25.00 \text { net } \\
& 0.521314259 \text { Paperback } 89.95 \text { net }
\end{aligned}
$$

\section{Cambridge University Press}

The Edinburgh Building, Shaftesbury Road, Cambridge CB2 2RU, England 


\section{Oxford University Press}

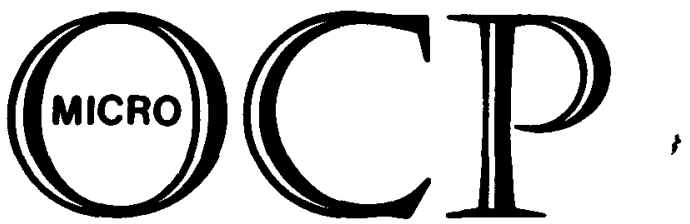

... a powerful tool for classicists interested in text analysis and the production of word lists, indexes and concordances

Micro-OCP is the microcomputer version of the well-known mainframe text analysis package, the Oxford Concordance Program.

Micro-OCP generates word lists, indexes and concordances from texts in a variety of languages and alphabets. Texts for analysis can be prepared using most word-processing programs or may be entered on a mainframe and downloaded onto a PC.

Features of particular interest to classicists include:

the facility to sort into Greek alphabetical order, allowing for accents and other diacritical marks

- the inclusion of two alphabets for transliterated Greek, including the Thesaurus Linguae Graecae scheme

most major classical Latin authors are already available in machine-readable form

Micro-OCP runs on the IBM PC, XT, or AT microcomputers. For further information on hardware requirements return the coupon below.

UK Price: $£ 250+$ VAT for an institution; $£ 165+$ VAT for an individual working on his/her own PC

Export Price: $\$ 395$ and $\$ 275$, respectively $+2$

For further information on Micro-OCP, return this coupon to Anne Yates, Oxford Electronic Publishing, OUP, Walton Street, Oxford OX2 6DP.

Name

OXFORD

Address ELECTRONIC PUDLSHING

Postcode

Country $\mathrm{CR} / 11$ 
ANNALS OF SCHOLARSHIP is a journal devoted to crossdisciplinary studies in the humanities and social sciences. The editors are especially interested in contributions related to the following topics: (1) E. R. Curtius (1886-1956) as a philologist, literary historian, cultural critic, or humanist; (2) the history of classical scholarship, with an emphasis on individual figures, publications, or controversies; (3) the sense of the term Postmodernism - whether it is a period label, the name of a specific cultural trend, etc.; (4) methodological studies in kinship, gender, and sexuality. The editors are also interested in receiving review essays offering substantial discussion of important new work in the humanities and social sciences, and articles discussing the work and careers of major scholars of all periods. Proposals from prospective contributors as well as finished articles are welcome. Contact the Editor, 1841 Broadway, New York, NY 10023-7699.

Annual subscriptions: institutions, $\$ 35.00$; individuals, $\$ 20.00$. Single numbers: $\$ 7.00$; foreign air mail, add $\$ 1.00$ per issue. Now available: issue 4.1, "Science and the Imagination"; issue 4.2 available in April 1987; issue 4.3 available in July.

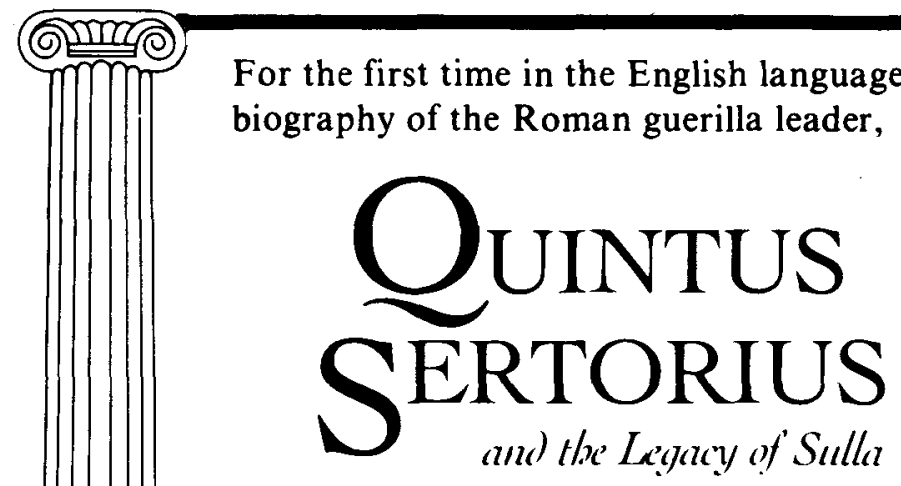

Classicist Philip Spann breaks new ground for English-language readers in this account of a military genius whose strategy and tactics are a virtual textbook for today's brushfire wars. For the scholar, Quintus Sertorius offers a fresh revelation of the confused loyalties that undermined a major experiment in representative government.

ISBN 0-938626-64-7

$\$ 22$ cloth

Send orders to:

The University of Arkansas Press, Fayetteville, AR 72701. VISA, EuroCard, personal cheques welcome. Please add $\mathbf{S I . 5 0}$ for handling.

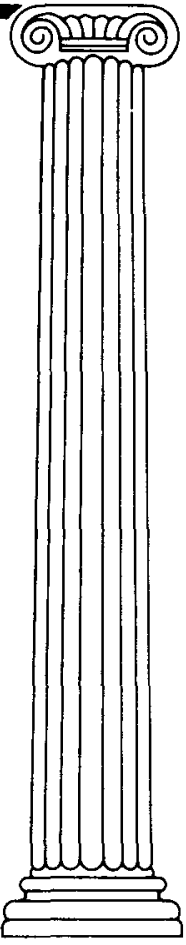

(iii) 


\section{CAMBRIDGE}

\section{Hispaniae}

Spain and the Development of Roman Imperialism, 218-82 BC

\section{J. S. RICHARDSON}

This book traces the beginnings and the first 140 years of the Roman presence in Spain, showing how what began as a purely military commitment developed into a range of civilian activities, including taxation and the founding of both Roman and native settlements. Thus the book is of major importance to an understanding of the spread of Roman power in this period throughout the Mediterranean world.

230 pp. $\quad 0 \quad 521321832 \quad \mathbf{8 2 5 . 0 0}$ net

\section{The Ruling Class of Judaea}

The Origins of the Jewish Revolt Against Rome AD 66-70

\section{MARTIN GOODMAN}

This book examines why in AD 66 a revolt against Rome broke out in Judaea. It shows that the ultimate cause of the revolt was a misunderstanding by Rome of the status criteria of Jewish society, and sheds light on Rome's inability to control a society with cultural values so different from its own.

288 pp. $\quad$ o $521334012 \$ 25.00$ net

\section{Listening to the Cicadas}

\section{A Study of Plato's Pbaedrus \\ G. R. F. FERRARI}

This is a full-length study of Plato's dialogue Pbaedrus, written in the belief that such concerted scrutiny of a single dialogue is an important part of the project of understanding Plato so far as possible 'from the inside' - of gaining a feel for the man's philosophy. The focus of this account is on how the resources both of persuasive myth and of formal argument complement and reinforce each other in his philosophy.

Cambridge Classical Studies

$320 p p . \quad O \quad 521 \quad 26778 \quad 1 \quad £ 22.50$ net

\section{Reissue}

Now in paperback

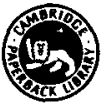

\section{The Origins of European Thought about the Body, the Mind, the Soul, the World, Time and Fate}

New Interpretations of Greek, Roman and Kindred Evidence, also of some Basic Jewish and Christian Beliefs

Second Edition

\section{RICHARD BROXTON ONLANS}

The reissue of this classic work makes available again a fascinating compendium of ideas, conjectures and explanations about life, mind, body, soul and human destiny which were embodied in the myths, legends and customs of the ancients. $608 p p . \quad 0 \quad 521351227$ Hard covers 635.00 net o 521347947 Paperback $\$ 12.50$ net

\section{Cambridge University Press}

The Edinburgh Building, Shaftesbury Road, Cambridge CB2 2RU, England 


\section{PRINCETON UNIVERSITY PRESS}

\section{Disguise and Recognition in the Odyssey Sheila Murnaghan}

The motifs of disguise and recognition of identity are commonly recognized as traditional features of the Odyssey's plot. Now this distinctive reading shows how those motifs are used not only to tell the story of Odysseus' return but also to explore the central values of Homeric society. In a world where identity is largely defined through the esteem of others, the recognition of identity represents the acknowledgement of heroic prestige. Cloth: \$28.00 IBSN 0-691-06716-3

\section{Horace's Poetic Journey}

A Reading of Odes 1-3

David H. Porter

"This is a bold and exacting piece of literary criticism that will offer a fresh measure by which to approach one of the great lyricists. Furthermore, it is one of the most convincing arguments for an ancient poet's arrangement of his own poetry into books and groups of books that I have seen." - Charles L. Babcock, The Ohio State University

Cloth: \$35.00 ISBN 0-691-06702-3

\section{Hadrian and the City of Rome}

Mary Taliaferro Boatwright

The Pantheon, the Temple of Venus and Roma, Hadrian's Mausoleum transformed into Castel Sant' Angelo, and his villa at Tivoli epitomize for many the power and resources of Rome at its zenith. Mary T. Boatwright compiles and assesses the varied evidence for Hadrian's buildings and for his administrative changes and evaluates his effect on the capital city in a topographical and historical context. A comprehensive catalogue follows the illustrated text.

Cloth: \$42.50 ISBN 0-691-03588-1

\section{NEW IN PAPERBACK}

\section{The Early Greek Concept of the Soul} Jan Bremmer

By confronting the Greek material with findings from social anthropology and folklore, Jan Bremmer achieves new insight into the early Greek concept of the soul and illuminates an important stage in the genesis of the Greek mind.

Paper: \$10.95 ISBN 0-691-10190-6 Cloth: \$24.50 ISBN 0-691-03131-2

PRICES ARE IN U.S.DOLLARS

ORDER FROM YOUR BOOKSELLER OR FROM

Princeton University Press

ORDER DEPT., 3175 PRINCETON PIKE, LAWRENCEVILLE, NEW JERSEY 08648 U.S.A. 


\section{Tragic Ways of Killing a Woman}

\section{NICOLE LORAUX}

'This is a brilliant and memorable study, displaying great imagination, learning and insight. Nicole Loraux treats the works of the tragedians together, at the same time respecting their differences ... Her book contains more, and is more rewarding than most books twice its length.' Bernard Williams

$£ 11.95$ Cloth 112pp 0-674-90225-4

\section{Ancient Mystery Cults \\ WALTER BURKERT}

The leading historian of Greek religion provides the first comprehensive, comparative study of the secret mystery cults which existed within the larger culture of the public religion of Greece and Rome.

$£ 15.95$ Cloth 176pp 0-674-03386-8

\section{The Sages}

Their Concepts and Beliefs EPHRAIM E. URBACH

The wisdom of the great religious teachers in classical Judaic thought is signalized in this landmark examination of the ancient texts that form the basis of the rabbinic code of ethics.

$£ 15.25$ Paper 1120pp 0-674-78523-1

\section{HARVARD}

UNIVERSITY PRESS 126 Buckingham Palace Road London SWIW 9SA 


\section{UNTERSUCHUNGEN ZUR ANTIKEN LITERATUR UND GESCHICHTE}

\section{RAINER M. J. JAKOBI \\ Der Einfluß Ovids auf den Tragiker Seneca}

1988. Largo-octavo. VIII, 238 pages. Cloth DM 116,ISBN 3110112647 (Volume 28)

A Compendium of imitations of Ovid in Seneca's tragedies presented in the form of a running parallel commentary. The comparative interpretation reveals the specific character of Senecas composition.

A commentary is on the texts and their authenticity.

in preparation:

JOACHIM DINGEL

Scholastica materia

Untersuchungen zu den Declamationes minores und der Institutio oratoria Quintilians

1988. Large-octavo. Approx. 270 pages. Cloth approx. DM 108,ISBN 3110114623 (Volume 29)

MICHAEL HILLGRUBER

\section{Die zehnte Rede des Lysias}

1988. Largo-octavo. Approx. 170 pages. 1988. Cloth approx. DM 94,ISBN 3110115565 (Volume 30) 


\section{CLASSICS, OLD AND NEW}

Four by Donald Kagan:

"Kagan's four volumes are a meticulous critical examination of the strategy of this classic confrontation between a great land power and a great naval power."

\section{THE FALL OF New! \\ THE ATHENIAN EMPIRE}

"Kagan's strategic analysis of this final phase of the long war is a remarkable achievement."-Bernard Knox, The Atlantic. * 13 maps. U.S. $\$ 43.45$

\section{THE OUTBREAK OF THE} PELOPONNESIAN WAR

Maps. U.S. $\$ 46.75$

THE ARCHIDAMIAN WAR

Maps. U. S. $\$ 43.45$

THE PEACE OF NICIAS AND THE SICILIAN EXPEDITION

Maps. U. S. $\$ 42.35$

THE ARCHAEOLOGY

OF GREECE

An Introduction

Revised Edition

By WILLIAM R. BIERS. "Wellwritten and exceptionally wellillustrated."-David Hunt, Times Literary Supplement. 8 color plates; 334 b-\&w illustrations. U. S. $\$ 19.75$ paper; U. S. $\$ 54.45$ cloth

THE ART AND CULTURE OF EARLY GREECE, 1100-480 B.C.

BY JEFFREY M. HURWIT.

"Hurwit produces a synthetic view of Greek culture-one that takes politics and philosophy into account as well."-Virginia Quarterly Review. 154 b\&w illustrations. U. S. \$18.65 paper; U. S. $\$ 60.50$ cloth

\section{MOMENTARY MONSTERS Lucan and His Heroes}

By W. R. JOHNSON. This book is a lively and provocative reading of the Roman poet Lucan (A.D. 39-65) which casts new light on his epic poem and only surviving work, the Pharsalia. "Entertaining, bristling with good humor and insight." - Charles Witke, University of Michigan. Cornell Studies in Classical Philology. U. S. \$19.75 cloth

\section{SENECA'S}

HERCULES FURENS

A Critical Text with Introduction and Commentary

By JOHN G. FITCH. Fitch's new Latin text of Seneca's play Hercules Furens is based on a collation of the chief manuscripts. His introduction traces the conflicting classical portrayals of Hercules - a figure embodying altruism and selfishness, restraint and wildness-and argues that in Seneca's play the untamed side of his nature destroys him. Cornell Studies in Classical Philology. U.S. $\$ 54.45$

\section{THE ROOTS OF POLITICAL PHILOSOPHY Ten Forgotten Socratic Dialogues}

Translated, with Interpretive Studies. Edited by THOMAS L. PANGLE. Each dialogue, presented in a literal English translation, is accompanied by an essay by an eminent political philosopher which illuminates aspects of Platonic political theory, aesthetics and ethics. U.S. \$14.25 paper;

U. S. $\$ 48.95$ cloth

\section{CORNELL UNIVERSITY PRESS}

c/o Trevor Brown Assoc., Suite 7, 26 Charing Cross Rd., London WC2H 0LN 


\title{
TABLE OF CONTENTS
}

\author{
Number 2
}

\section{REVIEWS}

Accattino, P. L'anatomia della città nella Politica di Aristotele (C. J. RowE) 282

Alföldi, A. Caesar in 44 v.Chr., I (E. RA wson)

Alföldi, A. Caesariana. Gesammelte Aufsätze zur Geschichte Caesars und seiner Zeit (E. RAWSON)

Alföldy, G. Die römische Gesellschaft (T. WIEDEMAN N)

Alföldy, G. Römische Heeresgeschichte (T. WIEDEMANN)

Anderson, G. Philostratus (J. R. MORGA N)

Andreae, B. Die Symbolik der Löwenjagd (R. R. R. SMITH)

Ballabriga, A. Le Soleil et le Tartare (R. G. A. BUXTON)

Behr, C. A. P. Aelius Aristides, The Complete Works Translated into English, I (A. R. R. SHEPPARD)

Benker, M. Achill und Domitian (M. DEW AR)

Benner, H. Die Politik des P. Clodius Pulcher (J. W. RICH)

Binder, G. (ed.) Saeculum Augustum, I (R. SE AGER)

Boardman, J., Vaphopoulou-Richardson, C. E. Chios (C. EMLYN-JONES) 305

Boatwright, M. T. Hadrian and the City of Rome (T. P. WISEMA N) 357

Bömer, F. P. Ovidius Naso, Metamorphosen: Kommentar, Buch XIV-XV (E. J. KENNEY) 247

Bossi, F. Studi sul Margite (J. SMAR T)

Boyle, A. J. Seneca's Phaedra (R. MAYER)

Briggs, W. W., Jr. The Letters of Basil Lanneau Gildersleeve (N. HOR SFAL L)

Brisson, L. Platon, Lettres (L. COVENTRY)

Broughton, T. R. S. The Magistrates of the Roman Republic, 3 (T. J. CADoux)

Cairns, F. (ed.) Papers of the Liverpool Latin Seminar, 5 (N. HORSFAL L)

Calboli Montefusco, L. La dottrina degli 'status' nella retorica greca e romana (i. C. RUTHERFORD)

Canto, M. L'Intrigue philosophique (R. S. W. HAWTREY)

Canto, M. Platon, Gorgias (L. COVEN TR Y)

Carter, J.C. The Sculpture of the Sanctuary of Athena Polias at Priene (C. E. VAFOPOULOU-RICHARDSON)

Chiarucci, P. Lanuvium (D. RIDGWAY)

Chiarucci, P. (ed.) Il Lazio antico dalla protostoria all' età medio-repubblicana (D. RIDGWA Y)

Cleary, J. J. (ed.) Proceedings of the Boston Area Colloquium in Ancient Philosophy, 2 (J. CREED)

Couloubaritsis, L. Mythe et philosophie chez Parménide (M. R. WRIGHT)

Coxon, A. H. The Fragments of Parmenides (M. R. WRIGH T)

De Puma, R. D. Corpus Speculorum Etruscorum, USA, 1: Midwestern Collections (F. R. SERRA RIDGWAY)

Dolbeau, F., Petitmengin, P., et al. Indices librorum (B. C. B A R KER-BENFIELD)

Donderer, M. Die Chronologie der römischen Mosaiken in Venetien und Istrien bis zur Zeit der Antonine (K. M. D. DUN B A BIN)

Dover, K. J. Greek and the Greeks: Collected Papers, I (H. LLOYD-JONES) 377

Eckstein, A. M. Senate and General (J. W. RICH) 
Epstein, D. F. Personal Enmity in Roman Politics, 218-43 B.C. (D. Nightingale) 319

Espinosa Ruiz, U. Epigrafia romana de la Rioja (J. S. RICHARDSON) 363

Falconi Amorelli, M. T. Vulci. Scavi Bendinelli (1919-1923) (D. RIDGWAY) 352

Fantuzzi, M. Bionis Smyrnaei Adonidis Epitaphium (R. MATTHEWs) 217

Ferguson, J. A Prosopography to the Poems of Juvenal (F. Jones) 255

Ferrari, G. R. F. Listening to the Cicadas (C. J. ROW E) 223

Fowden, G. The Egyptian Hermes (J. G. GRIFFITHS) 293

Frede, M. Essays in Ancient Philosophy (G. B. KERFERD) 290

Freyburger, G. Fides, Étude sémantique et religieuse depuis les origines jusqu'à l'époque augustéenne (J. H. W. G. LIEBESCHUET Z)

Freyburger-Galland, M. L., Freyburger, G., Tautil, J. C. Sectes religieuses en Grèce et à Rome dans l'antiquité païenne (J. H. W. G. LIEBESCHUETZ)

Giardina, A. (ed.) Tradizione dei classici, trasformazioni della cultura (H. D. JOCELYN) 365

Gold, B. K. Literary Patronage in Greece and Rome (N. HORSFALL) 268

Gratwick, A. S. Terence, The Brothers (P. JEFFREY S-POWELL) 239

Grimal, P. Rome: La Littérature et l'histoire (M. GRIFFIN) 379

Halfmann, H. Itinera principum (W. WILlıA S) 333

Halliwell, S. The Poetics of Aristotle (M. HEA TH)

Hansen, M. H. The Athenian Assembly in the Age of Demosthenes (P. J. RHOdEs) 310

Hanson, W. S. Agricola and the Conquest of the North (C. MARTIN) 330

Harder, A. Euripides' Kresphontes and Archelaos (J. WILKINS) 209

Heath, M. Political Comedy in Aristophanes (D. M. MACDOWELL) 215

Helttula, A. Studies on the Latin Accusative Absolute (J. N. ADAMS) 300

Henderson, J. Aristophanes, Lysistrata (D. M. MACDOWEL L) 213

Henig, M., King, A. (edd.) Pagan Gods and Shrines of the Roman Empire (J. H. W. G. LIEBESCHUET Z)

Herfort-Koch, M Archaische Bronzeplastik Lakoniens (P. CARTLEDG)

Hinds, S. The Metamorphosis of Persephone (W. S. M. NiCOLL) 245

Kovacs, D. The Heroic Muse: Studies in the Hippolytus and Hecuba of Euripides (S. IRELAND)

Kyrieleis, H. (ed.) Archaische und klassische griechische Plastik (J. BOA RDMAN)

Lamberton, R. Homer the Theologian (A. SHEPP A R D)

288

Lambrechts, R. Corpus Speculorum Etruscorum, Belgique I (F. R. SER RA RIDGWAY) 354

Lundström, S. Zur Textkritik der Tusculanen (J. G. F. POWELL) 257

Lyne, R. O. A. M. Further Voices in Vergil's Aeneid (N. HORSFALL) 243

McCann, A. M., et al. The Roman Port and Fishery of Cosa (A. J. PA R KER) 356

Marinatos, N. Minoan Sacrificial Ritual (B. C. DIETR ICH) 340

Modrak, D. K. W. Aristotle. The Power of Perception (S. LoviBond) 280

Moore-Blunt, J. Plato, Epistulae (D. B. ROBinson) 229

Morani, G. and M. Tragedie e frammenti di Eschilo (E. FLINTOFF) 205

Mouton, C. Aspects grecs - aspects russes à la lumière des traductions modernes de textes anciens (C. M. MACROBERT)

Olsen, B. M. L'Étude des auteurs classiques latins aux $X I^{e} e t X I I^{e}$ siècles (B. C. BA R KE RBENFIELD)

Osborne, R. Classical Landscape with Figures (R. A. KNOX)

Paschoud, P. Zosime, Histoire Nouvelle, (Livre V) (W. R. CHA LMERs)

Pigeaud, J. Folie et cures de la folie chez les médecins de l'antiquité gréco-romaine (v. NUTTON)

$\begin{array}{lr}\text { Pipili, M. Laconian Iconography of the Sixth Century B.C. (P. CA R TLEDGE) } & 342 \\ \text { Poe, J. P. Genre and Meaning in Sophocles'Ajax (M. COM BER) } & 207\end{array}$

Radice, W., Reynolds, B. (edd.) The Translator's Art: Essays in Honour of Betty Radice (R. STONEMAN) 


\section{CONTENTS}

Rengakos, A. Form und Wandel des Machtdenkens der Athener bei Thukydides (H. D. WESTLAKE)

Richardson, J. S. Hispaniae (†N. MACKIE)

Robinson, T. M. Heraclitus Fragments (E. HUSSEY)

Ross, D. O. Virgil's Elements (P. R. HARDIE)

Schachermeyr, F. Mykene und das Hethiterreich (D. F. EASTON) 303

Scodel, H. R. Diaeresis and Myth in Plato's Statesman (C. GIL L) 225

Seeskin, K. Dialogue and Discovery: a Study in Socratic Method (J. CREED) 277

Seiler, F. Die griechische Tholos (R. A. TOMLINSON)

Skinner, M. (ed.) Rescuing Creusa (J. F. GARDNER)

Sommerstein, A. H. The Comedies of Aristophanes, Vol. 6: Birds (w. G. AR Not T) 211

Spaltenstein, F. Commentaire des Punica de Silius Italicus (livres 1 à 8) (D. W. T. VESSEY) 254

Spann, P. O. Quintus Sertorius and the Legacy of Sulla (A. KEA VENEY) 321

Stoneman, R. Land of Lost Gods (D. CONSTANTINE)

Strauss, B. S. Athens after the Peloponnesian War (R. A. KNOX) 308

Syme, R. The Augustan Aristocracy (R. SEAGER)

Touloumakos, J. Die theoretische Begründung der Demokratie in der klassischen Zeit Griechenlands (C. J. ROWE)

Verdenius, W. J. Commentaries on Pindar, 1 (D. E. GER BER)

Veyne, P. (ed.) A History of Private Life, I: From Pagan Rome to Byzantium (s. C. HUMPHREYS)

Vieillefond, J.-R. Longus Pastorales (Daphnis et Chloé) (B. P. REA RDON)

Waelkens, M. Die kleinasiatischen Türsteine (R. R. R. SMITH)

Waldstein, W. Operae libertorum: Untersuchungen zur Dienstpflicht freigelassener Sklaven (T. E. J. WIEDEMAN N)

Wellesley, K. Cornelius Tacitus, I.2 Annales $X I-X V I$ (†N. P. MILLER)

Whitby, M., Hardie, P., Whitby, M. (edd.) Homo Viator (N, horSf A L L) 383

White, M. J. Agency and Integrality (P. M. HUBY) 286

Wiseman, T. P. Roman Studies (R. G. M. NIS BET)

Woodman, A. J. Rhetoric in Classical Historiography (T. P. WISEM A N) 262

Wuilleumier, P., Le Bonniec, H., Hellegouarc'h, J. Tacite, Les Histoires, Livre I (K. WELLESLEY)

Zanker, G. Realism in Alexandrian Poetry: a Literature and its Audience (A. J. WOODMAN)

Zwierlein, O. Senecas Phaedra und ihre Vorbilder (R. MAYER)

\section{NOTICES}

Åkerstrom, Å. Berbati (R. L. N. BARBER)

Andersen, L. Studies in Oracular Verses: Concordance to Delphic Responses in Hexameter (R. PARKER)

Balcer, J. M. Herodotus and Bisitun (R. STEVENSON)

Baldassarri, M. La logica stoica: testimonianze e frammenti, 5b, 7b, 8 (J. BAR NES)

Balme, M., Morwood, J. Oxford Latin Course (w. A. Williams)

Bernhardt, U. Die Funktion der Kataloge in Ovids Exilpoesie (M. J. MCGANN) 413

Bettini, M. Antropologia e cultura romana (A. DOUGLAS)

Biers, J. C. The Great Bath on the Lechaion Road (A. FARRINGTON)

Boese, H. Proclus Elementatio Theologica, translata a Guillielmo de Moerbecca (J. DILLON)

Bonanno, A. (ed.) Archaeology and Fertility Cult in the Ancient Mediterranean (J. M. A LONSO-NÚÑ̃ Z)

Bowen, A. Aeschylus Choephori (P. G. MASON) 


\section{CONTENTS}

Ceccarelli, L. L'allitterazione a vocale interposta variabile in Virgilio (s. J. HARRISON)

Cessi, V. Erkennen und Handeln in der Theorie des Tragischen bei Aristoteles (M. HEATH)

Cipriani, G. Cesare e la retorica dell' assedio (J. G. F. POWEL L)

Conacher, D. J. Aeschylus Oresteia: a Literary Commentary (M. DAVIES)

Cook, B. F. Greek Inscriptions (M. M. AUSTIN)

Deforge, B. Eschyle, poète cosmique (M. COM B ER)

Ferguson, J. Euripides, Hippolytus (G. T. COCK BUR N)

Flacelière, R., Irigoin, J., Sirinelli, J., Philippon, A. Plutarque, Oeuvres Morales, I.i (D. A. RUSSELL)

Fontaine, P. F. M. The Light and the Dark (R. W. JORDAN)

Fraisse, J.-C. L'Intériorité sans retrait (A. SHEPPARD)

Frere, S. Britannia (T. W. POT TER)

Frere, S. S., Rivet, A. L. F., Sitwell, N. H. H. Tabula Imperii Romani: Britannia Septentrionalis (L. KE P PIE)

Freundlich, R. Verbalsubstantive als Namen für Satzinhalte in der Sprache des Thukydides (M. H. B. MARSHALL)

Frisch, P. Zehn agonistische Papyri (J. D. THOMAS)

Frizell, B.S. Asine II, Results of the Excavations East of the Acropolis 1970-1974 (E. FRENCH)

Gallo, I. Greek and Latin Papyrology (J. D. тном AS)

Gascó, F., Ramírez de Verger, A. Elio Aristides. Discursos I (N. G. WILSON)

Gentili, B., Pretagostini, R. (edd.) Edipo: il teatro greco e la cultura europea (A. L. BROWN)

Godwin, J. Lucretius, De Rerum Natura IV (P. M. BROWN)

Grene, D. (tr.) Herodotus, The History (J. H A R T)

Grensemann, H. Knidische Medizin, II (V. NUTTON)

Grziwotz, H. Der moderne Verfassungsbegriff und die 'Römische Verfassung' in der deutschen Forschung des 19. und 20. Jahrhunderts (W. NIP PEL)

Hadot, I. Simplicius: sa vie, son oeuvre, sa survie (A. H. AR MSTRONG)

Hammond, M. (tr.) Homer, The Iliad (J. G. R ANDalL)

Higgins, R. Tanagra and the Figurines (C. E. VAFOPOULOU-RICHARDSON)

Högemann, P. Alexander der Grosse und Arabien (S. HOR N BLOWER)

Kenney, E. J. Moretum : a Poem Ascribed to Virgil (J. воотн)

Kühn, J.-H., Fleischer, U. Index Hippocraticus, Fasc. II, E-K (H. KING)

Kullman, W., Flashar, H., Hampl, F. Mythos. Deutung und Bedeutung (A. GRIFFITHS)

Labate, M. L'arte di farsi amare (A. H. F. GRIFFIN)

Leclant, J., Clerc, G. Inventaire bibliographique des Isiaca, L-Q (J. G. GRIFFITHS)

Lombardo, S., Rayor, D. (tr.) Callimachus, Hymns, Epigrams, Select Fragments (N. HOPKINSON)

Manolidis, G. Die Rolle der Physiologie in der Philosophie Epikurs (R. W. JORD AN)

Marshall, M. H. B. Verbs, Nouns and Postpositives in Attic Prose (A. C. MOOR HOUSE)

Masullo, R. Marino di Neapoli, Vita di Proclo (A. ShePPAR D)

Miller, N. Tacitus Annals 14: a Companion to the Penguin Translation with Introduction and Commentary (A. J. WOODMAN)

Morrow, G. R., Dillon, J. M. (tr.) Proclus' Commentary on Plato's Parmenides (H. J. BLUMENTHAL)

Müller, C. W. Erysichthon (N. HOPK INSON)

Murnaghan, S. Disguise and Recognition in the Odyssey (R. B. RUTHERFORD) 


\section{CONTENTS}

Ostenfeld, E. Ancient Greek Psychology and the Modern Mind-body Debate (C. GIL L) 427

Oudemans, Th. C. W., Lardinois, A. P. M. H. Tragic Ambiguity (s. D. GOLDHIL)

Paroussis, M. Les Listes de champs de Pylos et Hattuša et le régime foncier mycénien et hittite (J. T. HOOKER)

Philipp, H. Mira et magica (M. HENIG)

Porter, D. H. Only Connect (M. CoMBER)

420

Pucciarelli, E. I Cristiani e il servizio militare (E. D. HUNT)

Ramage, E. S. The Nature and Purpose of Augustus' Res Gestae (J. CAR TER)

Rathofer, C. Ciceros Brutus als literarisches Paradigma eines Auctoritas-Verhältnisses (A. DOUGLAS)

Remy, B. L'Évolution administrative de l'Anatolie aux trois premiers siècles de notre ère (S. MITCHELL)

Riikonen, H. K. Menippean Satire as a Literary Genre with Special Reference to Seneca's Apocolocyntosis (R. ASTBUR Y)

Robinson, T. A. Greek Verb Endings (M. H. B. MAR SH A L L)

Romano, E. La capanna e il tempio: Vitruvio o dell' architettura (E. RAWSON)

Rosenmeyer, T. G. Deina ta polla (s. D. GOLDHILL)

Ruck, C. A. P. Latin: a Concise Structural Course (P. JEFFREYS-POWELL)

Salanitro, G. Theodorus Gaza: M. Tullii Ciceronis liber de senectute in Graecum translatus (J. G. F. POWELL)

Scatozza Höricht, L. A. Il volto dei flosofi antichi (R. R. R. SMITH)

Serpa, F. Il punto su: Virgilio (N. HORSF A L L)

Sherk, R. K. Rome and the Greek East to the Death of Augustus (M. H. CR A WFORD)

Silk, M. S. Homer, The Iliad (J. B. HAINS WOR TH)

Soren, D. (ed.) Excavations at Kourion, Cyprus. The Sanctuary of Apollo Hylates (E. J. PELTENBURG)

Sosower, M. L. Palatinus Graecus 88 and the Manuscript Tradition of Lysias (D. M. MACDOWELL)

Sutton, D. F. Two Lost Plays of Euripides (E. M. CRAIK)

Trypanis, C. A. Sophocles, Three Theban Plays (s. I E L A ND)

Turner, E. G. Greek Manuscripts of the Ancient World (N. G. WILsON)

Väänänen, V. Le Journal-Épitre d'Égérie (Itinerarium Egeriae) (M. WINTER BOTTOM)

Van der Meer, L. B. The Bronze Liver of Piacenza (D. R IDGWA Y)

Wagner, H. Aesthetik der Tragödie (M. S. sıLK)

Waithe, M. E. (ed.) A History of Women Philosophers (G. CLAR K)

Waszink, J. H., Van Winden, J. C. M. Tertullian's De Idololatria (R. P. C. HANson) 419

Wengst, K. Pax Romana and the Peace of Jesus Christ (R. P. C. HANSON)

West, M. L. Euripides, Orestes (G. T. COCK BUR N)

Williams, R. D. The Aeneid (N. HORSFALL) 4410

Wooten, C. W. Hermogenes, On Types of Style (S. USHER) 406

$\begin{array}{lr}\text { BOOKS RECEIVED } & 457\end{array}$

$\begin{array}{lr}\text { INDEXES } & 471\end{array}$

Authorization to photocopy items for internal or personal use, or the internal or personal use of specific clients, is granted by Oxford University Press for users in the USA registered with the Copyright Clearance Center (CCC0 Transactional Reporting Service, provided that the base fee of $\$ 3.00$ per copy is paid directly to CCC, 27 Congress Street, Salem, MA 01970. For those organisations that have been granted a photocopy licence by $\mathrm{CCC}$ a separate system of payment has been arranged. The fee code for users of the Transactional Reporting Service is: ISSN/88 \$3.00. 


\section{UNTERSUCHUNGEN ZUR ANTIKEN \\ LITERATUR UND GESCHICHTE}

\section{MICHAEL HILLGRUBER \\ Die zehnte Rede des Lysias \\ Einleitung, Text und Kommentar mit einem Anhang uiber die Gesetzesinterpretation bei den attischen Rednern}

1988. Large-octavo. XVIII, 124 pages. Cloth DM 82,ISBN 3110115565 (Volume 29)

Apart from providing a philological and historical commentary on the text, the author attempts to elucidate the background to the trial and the nature of the case being heard and to gain new insights into the Attic orators' legal interpretations.

in preparation:

THEODOR HIRSCHBERG

\section{Senecas Phoenissen}

Einleitung und Kommentar

1988. Large-octavo. Approx. 180 pages. Cloth approx. DM 92,ISBN 3110116308 (Volume 30) 